\title{
Alcohol and other drug use, and mental distress in the women's universe
}

\author{
Uso de álcool, outras drogas e sofrimento mental no universo feminino \\ Alcohol, otras drogas y sufrimiento mental en el universo femenino
}

\section{Fernando José Guedes da Silva Júnior' ORCID: 0000-0001-5731-632X \\ Claudete Ferreira de Souza Monteiro" ORCID: 0000-0003-0902-3340}

'Universidade Federal do Piauí. Teresina, Piauí, Brazil.

How to cite this article:

Silva Jr FJG, Monteiro CFS. Alcohol and other drug use, and mental distress in the women's universe.

Rev Bras Enferm. 2020;73(1):e20180268. doi: http://dx.doi.org/10.1590/0034-7167-2018-0268

\section{Corresponding Author:}

Fernando José Guedes da Silva Júnior

E-mail: fernandoguedes@ufpi.edu.br

EDITOR IN CHIEF: Antonio José de Almeida Filho

Submission: 04-24-2018

Approval: 09-04-2018

\begin{abstract}
Objective: to analyze the relationship between alcohol and other drug use, and mental distress among women. Method: an analytical cross-sectional study conducted with 369 women in Piauí State. Alcohol Use Disorders Identification Test, Non-Student Drugs Use Questionnaire and Self-Reporting Questionnaire and inferential statistics were used. Results: women with heavy alcohol consumption (zone IV - possible dependence) are 2.1 times more likely to have mental distress. Consuming tobacco increases the odds of distress $3.5 \%$, tranquilizers 2.6 times and cannabis 4.5 times. There is a statistically significant and positive correlation between the Alcohol Use Disorders Identification Test score and the SelfReporting Questionnaire $(p=0.000 ; r=0.250)$. Conclusion: alcohol, tobacco, tranquilizers and cannabis use is associated with mental distress. The more intense the alcohol consumption, the more intense the mental distress. Therefore, it is necessary to track alcohol and other drug consumption, and mental distress in the routine care of women.

Descriptors: Mental Disorders; Mental Health; Alcoholism; Street Drugs; Women.
\end{abstract}

\section{RESUMO}

Objetivo: analisar a relação entre uso de álcool, outras drogas e sofrimento mental entre mulheres. Método: estudo analítico, transversal, realizado com 369 mulheres no Piauí. Utilizouse Alcohol Use Disorders Identification Test, Non-Student Drugs Use Questionnaire e Self-Reporting Questionnaire e estatística inferencial. Resultados: mulheres com padrão de consumo de álcool intenso (zona IV - possível dependência) possuem 2,1 vezes mais chance de ter sofrimento mental. Consumir tabaco aumenta em 3,5 vezes as chances desse sofrimento, tranquilizantes em 2,6 vezes e cannabis em 4,5 vezes. Há correlação estatisticamente significativa e positiva entre o escore do Alcohol Use Disorders Identification Test e do Self-Reporting Questionnaire ( $p$ $=0,000 ; r=0,250$ ). Conclusão: uso de álcool, tabaco, tranquilizantes e cannabis está associado ao sofrimento mental. Quanto mais intenso o consumo de álcool, mais intenso o sofrimento mental. Portanto, faz-se necessário o rastreamento do consumo de álcool, outras drogas e sofrimento mental na rotina de atendimento à mulher.

Descritores: Transtornos Mentais; Saúde Mental; Alcoolismo; Drogas llícitas; Mulheres.

\section{RESUMEN}

Objetivo: analizar la relación entre consumo de alcohol, otras drogas y trastornos mentales entre las mujeres. Método: estudio transversal analítico realizado con 369 mujeres en Piauí. Se utilizaron lo Alcohol Use Disorders Identification Test, lo Non-Student Drugs Use Questionnaire y el Self-Reporting Questionnaire y las estadísticas inferenciales. Resultados: las mujeres con alto consumo de alcohol (zona IV - posible dependencia) tienen 2,1 veces más probabilidades de tener problemas mentales. El consumo de tabaco aumenta las probabilidades de este sufrimiento en 3,5 veces, los tranquilizantes en 2,6 veces y el cannabis en 4,5 veces. Existe una correlación estadísticamente significativa y positiva entre la puntuación de lo Alcohol Use Disorders Identification Test y de lo Self-Reporting Questionnaire ( $p=$ 0,$000 ; r=0,250$ ). Conclusión: el consumo de alcohol, tabaco, tranquilizantes y cannabis se asocia con trastornos mentales. Cuanto más intenso es el consumo de alcohol, más intenso es el sufrimiento mental. Por lo tanto, es necesario hacer un seguimiento del consumo de alcohol, otras drogas y trastornos mentales en el cuidado de rutina de las mujeres.

Descriptores: Trastornos Mentales; Salud Mental; Alcoholismo; Drogas ilícitas; Mujeres. 


\section{INTRODUCTION}

Historically, Brazilian health policies aimed at women had limited scope, as they reflected demands related to pregnancy and childbirth, with a still reductionist conception of women's care (no longer encompassing issues related to the multidimensionality of the female universe, which would enable effective comprehensive care).

Notwithstanding the undeniable progress of these public policies directed at this social group, new demands for health care are reinforcing the need for a transdisciplinary approach to problem solving in order to contemplate a larger spectrum of female living. Situations such as alcohol and other drug use deserve further attention due to their rapid growth and the consequences for physical, mental, social health as well as legal and economic implications.

Although psychoactive substance use is a phenomenon mainly associated with the male population, there has been a significant decrease in the gap between men and women, due to the easy access to these substances and the changes in women's lifestyle in the last century ${ }^{(1)}$.

Among women, drug use still causes stigma, as it is a conduct that does not match the roles and functions socially established for women. It is associated with promiscuity, immorality and the inability to care for the family. Moreover, they make them vulnerable to situations of violence, favoring the development of mental distress ${ }^{(2)}$.

This clinical syndrome called "mental distress","common mental distress" or "common mental disorder" is a combination of three symptom groups that include sadness/discouragement, anxiety and physical symptoms (somatization). This terminology has been used to designate health situations in which the individual presents these symptoms with sufficient intensity to interfere with their daily activities without necessarily meeting the formal diagnostic criteria contained in the Diagnostic and Statistical Manual of Mental Disorders, $5^{\text {th }}$ Edition (DSM-V) and $10^{\text {th }}$ Revision of the International Statistical Classification of Diseases and Related Health Problems (ICD-10) ${ }^{(3)}$.

World distress projections for 2030 are worrisome as they are likely to be among the most disabling ${ }^{(4)}$. In Brazil, its prevalence ranges from $28.7 \%$ to $53 \%$, being considered high by scholars in the area. Special attention should be given to women, considering that mental distress is more prevalent in this group ${ }^{(5)}$.

One of the places where professionals approach alcohol and other drug users is Primary Health Care (PHC). In this context, there are multiple challenges both in identifying the harmful alcohol and other drug use and in the clinical syndrome known as mental distress. In the female universe, the screening and identification of this problem is even more complex due to social paradigms.

\section{OBJECTIVE}

To analyze the relationship between alcohol, other drug use, and mental distress among women.

\section{METHOD}

\section{Ethical aspects}

The study was approved by the Research Ethics Committee of Universidade Federal do Piauí (Opinion 1.630.831), in compliance with the ethical requirements proposed by Resolution 466/12 of the Brazilian National Health Board (Conselho Nacional de Saúde). The interview with women obeyed ethics, confidentiality and autonomy principles. Participants were informed about the risks and benefits of the research and about the freedom to accept or not to participate in the study. Those who agreed to participate signed a written consent term.

\section{Design, place of study and period}

This is an analytical and cross-sectional study, developed through an epidemiological survey, in Basic Health Units (BHU) of host cities of the five health macroregions of Piauí State. Data collection was performed from August 2015 to March 2016.

\section{Sample; inclusion and exclusion criteria}

The reference population consisted of 347,414 women aged 20 to 59 years ${ }^{(6)}$. The presumed prevalence of alcohol consumption among women was $39 \%{ }^{(7)}, 95 \%$ confidence level and $5 \%$ maximum error. A sample of 369 women was obtained. Proportional stratification among the five municipalities was obtained, obtaining 232 in Teresina, 36 in Parnaíba, 46 in Picos, 38 in Floriano and 17 in Bom Jesus.

The inclusion criteria were to be aged between 20 and 59 years old and to be attended at nursing consultations in the referred UBS. The exclusion criterion adopted in the study was women with mental illness records in their medical records. When approaching women who met the exclusion criteria, a new participant was drawn.

\section{Study protocol}

Women recruitment was by lot. Excel 2010 software was used, considering the numerical listing of women attended at the respective UBS. Approach to women was performed through partnership between the nurse and the data collection team during nursing consultation. The average time to obtain data was 40 minutes.

Information of interest was obtained from the application of a questionnaire with questions about sociodemographic and economic variables. To assess alcohol consumption, the Alcohol Use Disorders Identification Test (AUDIT) was use. This tool was translated, validated and adapted to the Brazilian reality. In this tool, answers to each question are scored from 1 to 4 and predict four risk zones: zone I (up to 7 points: indicates low risk use or abstinence); zone II (8 to 15 points: indicates hazardous use); zone III (16 to 19 points: suggests harmful use) and zone IV (over 20 points: shows a possible dependence) ${ }^{(8)}$. To assess tobacco and illegal drug use, the Non-Student Drugs Use Questionnaire (NSDUQ) was used ${ }^{(9)}$.

Mental distress was assessed from the Self-Reporting Questionnaire (SRQ-20), an instrument composed of 20 yes/no questions, of which 4 address aspects related to physical symptoms and 16 about psycho-emotional disorders. The SRQ-20 cutoff score for this study was set at $7 / 8^{(10)}$.

\section{Analysis of results, and statistics}

The data obtained were submitted to statistical processing in the Statistical Package for Social Science (SPSS) software, version 20.0. Descriptive statistics were performed, such as measures of 
central tendency (simple and average frequency) and measure of dispersion (Standard Deviation).

The Kolmogorov-Smirnov test was performed to verify the normality assumption, and a non-normal distribution pattern was found. To observe the difference between the means, the nonparametric Mann-Whitney and Kruskal-Wallis test was applied.

To verify association among qualitative variables, the unadjusted Odds Ratio (OR) linear regression test was used. The strength of associations between variables was measured by OR and confidence intervals $(95 \% \mathrm{Cl})$. Spearman's correlation test was performed to assess associations among quantitative variables.

\section{RESULTS}

The sample consisted predominantly of young adult women (20-39 years) (75.1\%). Most declared themselves brown (59.4\%), married/stable union (71.8\%), heterosexual (98.6\%), Catholic (60.9\%) and with children (70.7\%). The majority had, on average, 10 years of study (Standard Deviation $=3.5$ ) and in public school $(86.8 \%)$. Regarding occupation, $57.3 \%$ reported having formal employment, with average individual income of 799.8 reais (reais is a Brazilian currency, which is about 199.95 US dollars) (Standard Deviation $=637.0$ ).

The prevalence of alcohol consumption was $50.1 \%(\mathrm{Cl} 44.5-$ 55.6), tobacco, $17.9 \%(\mathrm{Cl}=13.8-22.0)$, tranquilizers, $15.7 \%(\mathrm{Cl}$ = 11.7-19.7), solvents (cobbler glue, loló (smell of loló or loló is the popular name for a clandestinely prepared narcotic based on chloroform and ether) or perfume spear), $1.9 \%(\mathrm{Cl}=0.5-3.3)$, cannabis, $4.9 \%(\mathrm{Cl}=2.7-7.3)$ and cocaine, $1.9 \%(\mathrm{Cl}=0.5-3.5)$.

Table 1 - Linear logistic regression of alcohol, tobacco, tranquilizers, solvents, cannabis, cocaine, and other drug use with mental distress, Teresina, Piauí, Brazil, $2016(\mathrm{~N}=369)$

\begin{tabular}{|c|c|c|c|c|}
\hline \multirow[b]{2}{*}{$\begin{array}{l}\text { Independent } \\
\text { variables }\end{array}$} & \multicolumn{4}{|c|}{ Self-Reporting Questionnaire (SRQ-20) } \\
\hline & $\begin{array}{c}\text { Mental } \\
\text { distress } \\
\text { n(\%) }\end{array}$ & $\begin{array}{c}\text { No mental } \\
\text { distress } \\
\mathbf{n}(\%)\end{array}$ & $\begin{array}{l}\text { (un) } \\
\text { OR }\end{array}$ & $95 \% \mathrm{Cl}$ \\
\hline \multicolumn{5}{|c|}{ Alcohol comsumption } \\
\hline Zone I(*) & $102(33,2)$ & $207(66,8)$ & & \\
\hline Zone II & $28(54,9)$ & $23(45,1)$ & 0,8 & 20,$5 ; 21,8$ \\
\hline Zone III & $3(50,0)$ & $3(50,0)$ & 0,6 & 0,$1 ; 22,0$ \\
\hline Zone IV & $4(80,0)$ & $1(20,0)$ & 2,1 & $1,4-2,9$ \\
\hline Tobacco & & & & 2,$0 ; 6,1$ \\
\hline Yes & $41(62,1)$ & $25(37,9)$ & 3,5 & \\
\hline $\mathrm{No}(*)$ & $96(31,7)$ & $207(68,3)$ & & \\
\hline Tranquilizers & & & & 1,$4 ; 4,6$ \\
\hline Yes & $33(56,9)$ & $25(43,1)$ & 2,6 & \\
\hline $\mathrm{No}(*)$ & $104(33,4)$ & $207(66,6)$ & & \\
\hline Solvents & & & & 0,$5 ; 10,4$ \\
\hline Yes & $4(57,1)$ & $3(42,9)$ & 2,2 & \\
\hline $\mathrm{No}\left({ }^{*}\right)$ & $133(36,7)$ & $229(63,3)$ & & \\
\hline Cannabis & & & & 1,$6 ; 13,6$ \\
\hline Yes & $13(72,2)$ & $5(27,8)$ & 4,8 & \\
\hline $\mathrm{No}(*)$ & $124(35,3)$ & $227(64,7)$ & & \\
\hline Cocaine & & & & 0,$2 ; 5,7$ \\
\hline Yes & $3(42,9)$ & $4(57,1)$ & 4,8 & \\
\hline $\mathrm{No}(*)$ & $134(37,0)$ & $228(63,0)$ & & \\
\hline
\end{tabular}

Note: (un)OR = unadjusted Odds Ratio.
Linear logistic regression showed that women with a higher alcohol consumption pattern (zone IV - possible dependence) are 2.1 times more likely to have mental distress when compared to abstinent or at-risk women (zone I) $(\mathrm{Cl}=1.4-2.9)$. The same model also showed that smoking, tranquilizers and cannabis is associated with mental distress. Tobacco use increases by 3.5 times the odds for distress $(\mathrm{Cl}=2.0-6.1)$, tranquilizers by 2.6 times $(\mathrm{Cl}=1.4-4.6)$ and cannabis by 4.5 times $(\mathrm{Cl}=1.6-13,6)($ Table 1$)$.

Table 2 - Comparison of SRQ-20 averages with alcohol and other drug use, Teresina, Piauí, Brazil, 2016 ( $\mathrm{N}=369$ )

\begin{tabular}{lccccc}
\hline \multirow{2}{*}{ Variables } & \multicolumn{5}{c}{ Self-Reporting Questionnaire } \\
& & $\mathbf{n}$ & $\begin{array}{c}\text { X } \\
\text { (SRQ-20) }\end{array}$ & $\mathbf{p}$ & \\
\hline \multirow{2}{*}{ AUDIT } & Zone I & 307 & 5,4 & 3,8 & \\
& Zone II & 51 & 7,9 & 4,7 & $<0,01^{\text {(a) }}$ \\
& Zone III & 6 & 8,3 & 3,7 & \\
& Zone IV & 5 & 8,2 & 2,8 & \\
Tobacco & Yes & 66 & 8,0 & 4,0 & $<0,01$ \\
& No & 303 & 5,4 & 3,9 & \\
Tranquilizers & Yes & 58 & 8,0 & 4,5 & $<0,01$ \\
& No & 311 & 5,5 & 3,8 & \\
Solvents & Yes & 7 & 9,1 & 5,7 & 0,03 \\
& No & 362 & 5,8 & 4,0 & \\
Cannabis & Yes & 18 & 8,7 & 3,4 & $<0,01$ \\
& No & 351 & 5,7 & 4,0 & \\
Cocaine & Yes & 7 & 5,7 & 2,1 & 0,92 \\
& No & 362 & 5,8 & 4,0 & \\
& & & &
\end{tabular}

Note: $p$ value was obtained by the Mann-Whitney test and when = (a) by the Kruskal-Wallis test. Statistical significance was set at $p \leq 0.05$.

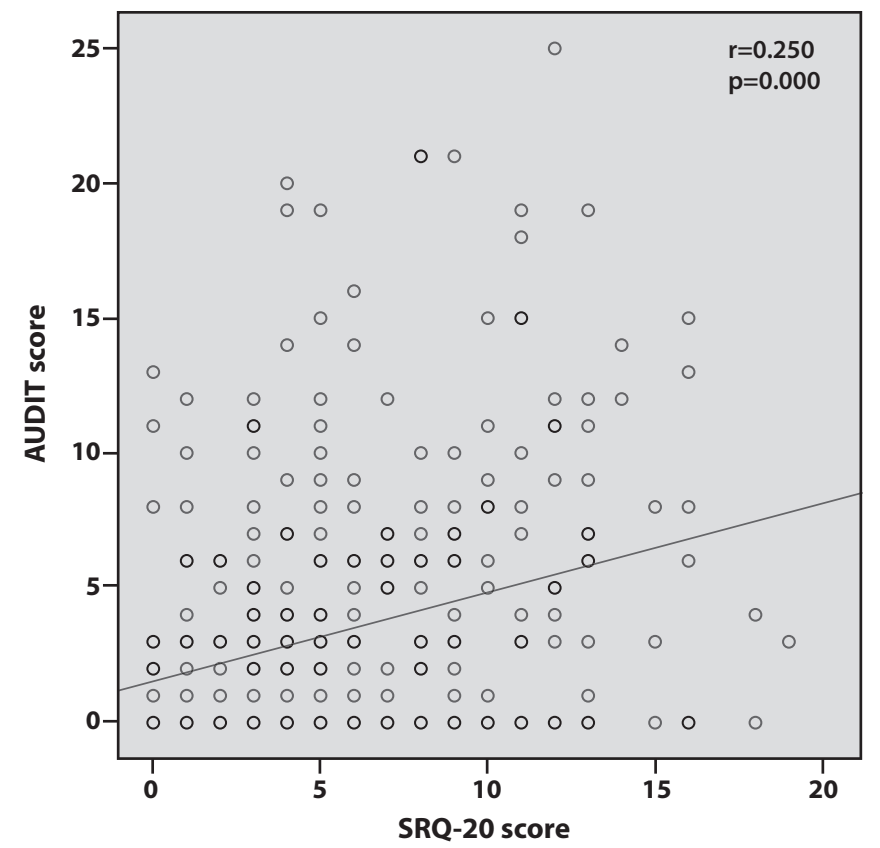

Figure 1 - Correlation between alcohol consumption assessment score (AUDIT) and mental distress assessment score (SRQ-20), Teresina, Piauí, Brazil, $2016(\mathrm{~N}=369)$ 
Women with a harmful use pattern (zone III) and possible dependence (zone IV) were found to have a mean SRQ-20 score suggestive of mental distress: \pm 8.3 and \pm 8.2 , respectively $(p<0.01)$. There is also a statistically significant difference in the mean SRQ-20 score of women who reported tobacco use $(p<0.01)$, tranquilizers $(p<0.01)$, solvents $(p=0.03)$ and cannabis $(p<0.01)$, and all SRQ-20 means suggestive of mental distress (Table 2 ).

Figure 1 shows that there is a statistically significant and positive correlation between the AUDIT score and the SRQ-20 score ( $p=0.000 ; r=0.250$ ). Moreover, the more intense the alcoholic beverage consumption, the more intense the mental distress.

\section{DISCUSSION}

In this study, there was a predominance of young adults, brown, married, Catholic, with children, who had, on average, 10 years of study in public school, with formal employment and average income of 799.80 reais. These results were similar to other studies conducted with women attending $\mathrm{PHC}^{(11-13)}$.

Although the socio-demographic and economic characteristics of most of women in this study are not entirely unfavorable, as they have high school, formal employment and income equivalent to a minimum wage, they are still not immunity conditions for alcohol and illegal drug use, among others. situations that affect women's physical and mental health.

Regarding alcohol consumption, the study shows a prevalence of $50.1 \%$. This indicator brings damages that are not limited to the woman herself, but also affects the alteration of the internal balance of families, materialized in the breakdown and/or fragmentation of affective relationships, in situations of domestic violence and reproduction of these harmful practices by other members. Alcohol consumption by most women in this study converges with data from the World Health Organization ${ }^{(14)}$, when it states that alcohol consumption by women has grown in several countries and has been approaching that of men who historically have always been greater. In Brazil, an epidemiological study has shown that alcohol consumption by women has grown linearly ${ }^{(15)}$.

In this study, although low-risk use was raised as the most prevalent mode of drinking (83.2\%), binge drinking has been observed in the women's universe. It is believed that all the social achievements of women in recent decades, including education, work, income, among other variables, carry with them a burden of responsibilities that were not previously their own and, therefore, can be predictive of this new form of drinking by this group.

An American systematic review study, which included 56 publications published between 1980 and 2013, showed that the intensification of alcohol consumption by American women has become a serious problem. $4.9 \%$ of women meet diagnostic criteria for alcohol dependence. Of these, $19.5 \%$ are victims of disorders associated with this practice and approximately 23,000 women are killed each year due to behaviors associated with excessive alcohol use ${ }^{(16)}$.

In Brazil, other data on this type of consumption are also pointed out when analyzing the data from the I and II National Survey on Drug Use and Health (NSDUH) conducted in 2006 and 2012 , respectively. In these surveys, binge drinking by women increased from $36 \%$ to $49 \%{ }^{(7,17)}$. This indicator draws attention, given that the continuous progression of this mode of consumption by the female population can be configured as a facilitating path for the development of addiction and all the weather to which this practice is associated, including mental distress.

Women's harmful habits are not restricted to alcohol use. There was also reference to tobacco use by $17.9 \%$ of the sample. The reasons related to experimentation and dependence on this substance vary according to socioeconomic, demographic, psychological and cultural variables.

Women have been targeted by the tobacco industry marketing in an attempt to reduce the smoking gap between men and women. This incentive is based on conveying emancipation ideas to transmission of false images of vitality, elegance, sophistication, and modernity ${ }^{(18)}$.

The need to use more affordable substances or perhaps the search for new sensations may have influenced the women in this study to also use illegal drugs such as tranquilizers (without a prescription), cannabis, solvents and cocaine.

With regard to illegal drug use, specifically, data from the World Drug Report published by the United Nations Office on Drugs and Crime $^{(19)}$ show that while men are three times more likely to use cannabis, cocaine and amphetamine, women are more likely to use opioids and tranquilizers without prescription.

In this study, attention is also drawn to mental distress, which is a syndrome known as a set of nonpsychotic symptoms such as insomnia, fatigue, irritability, forgetfulness, difficulty concentrating, and somatic complaints that are often not covered by the diagnostic criteria of the international classifications ${ }^{(3)}$.

Mental distress universally affects people of all ages, economic classes and countries. This fact has had major economic repercussions for society and a fall in the quality of life of individuals and families. However, exposure to factors such as insecurity and hopelessness, rapid social changes, alcohol consumption, other drugs and, consequently, greater exposure to situations of violence, makes women more vulnerable to this distress ${ }^{(20)}$.

Characteristics of social vulnerability, such as low socioeconomic status and education, are important psychosocial stressors pointed by the international literature also as predictors of worse mental health conditions, as they potentiate the occurrence of depression and anxiety ${ }^{(21)}$.

Few international studies analyze mental distress from a gender perspective, which makes it difficult to discuss how this problem interferes with these women's lives. However, there is evidence that sex is a determining factor in mental illness, since patterns of distress among women are different from those observed among men ${ }^{(22)}$.

In Brazil, although there is a growing concern about mental distress and all its implications, the difficulty in identifying this problem has a lack of knowledge about this object. Generally this demand is classified as polycystic, psychosomatic, functional, psychofunctional, hysterical and pathetic pithathic ${ }^{(23)}$.

Mental distress trivialization is reinforced when individuals report practices that are often reprimanded, marginalized or even criminalized by the general population, such as alcohol and other drug use. This is especially true when the protagonists of these habits are women, as gender differences still exist in the 
acceptance of these practices, as well as in the way men and women relate to psychoactive substances.

Women often seem to find in this consumption emotional support for their anxieties and concerns. Among men, use seems to be related to leisure time or integration with friends. Gender differences also extend to implications of this practice: Women who drink alcohol in a manner deemed problematic have a higher prevalence of mental distress and/or psychiatric disorders compared to men ${ }^{(24)}$.

Association between mental distress and alcohol use varied according to risk zones. Women in possible dependence are more vulnerable to mental distress than those in abstinence or risky use. Study confirms that as this consumption becomes more intense, there is a growing increase in mental distress, mainly linked to the mood domain and observed through symptoms of depression and anxiety ${ }^{(25)}$.

Considering mental distress as a syndrome consisting of a clinical triad of depressive, anxiety and somatization symptoms, special attention should be given to depressive symptoms, since a study of 188 alcoholics found that $63.8 \%$ of the sample had depression ${ }^{(26)}$.

In this study, it was found that the severity of psychopathological damage, assessed from SRQ-20, increases as the pattern of alcohol consumption intensifies. Although discreet, it was observed that the severity of mental distress is more intense in zone III (harmful use) than in zone IV (possible dependence). Regarding this fact, it should be considered that in the dependence on psychoactive substances there may be inaccuracies of information due to memory impairments caused by alcohol consumption, since cognitive losses arising from alcohol consumption are frequent. These losses begin at a young age and worsen over time, as it is assumed that there is a continuum in alcohol dependence, whose losses are cumulative ${ }^{(27)}$.

Mental distress is also associated with tobacco use in this study. This implication, as well as those related to alcohol consumption, is influenced by gender. Smoking by men and women should be interpreted as a multifaceted phenomenon, which has the complexity imprinted by social norms that shape the acceptance and use pattern of this substance.

Without disregarding gender influence, several other mechanisms should be considered to explain the association of smoking with mental distress. However, the strongest evidence is related to the biological dimension of drug dependence related to the neuropharmacological effects of nicotine in neurotransmitter systems linked, for example, to depressive symptoms. There is also evidence that nicotine may interact differently in the body during the menstrual cycle and cause different reactions from men ${ }^{(28)}$.

The findings of this research indicate that tranquilizers and cannabis were among the illegal drugs associated with mental distress. Despite its importance as a public health problem, relatively little is known about the natural course of cannabis use disorders ${ }^{(29)}$.

Rapid progression from the first cannabis use is responsible for the intense onset of symptoms of mental distress among women, and this outcome is also influenced by age of experimentation and individual psychiatric risk factors. However, they have achieved cessation of this habit and significantly faster recovery of symptoms than men ${ }^{(30)}$.
Most often benzodiazepine tranquilizers are often used for seeking relief from frustration or stress (49\%) and/or curiosity $(37 \%)^{(31)}$. Although these substances act biologically in the depression and anxiety dimensions, the relationship between the consumption of these substances and mental distress has not been investigated by other studies. There is only evidence that its use is associated with personality disorders ${ }^{(32-33)}$.

Solvents, in turn, by their very depressing nature, are substances capable of acting in the body and having repercussions through changes in the patterns of psychic mood function. Special attention should be given to solvent/inhalant use as this use significantly increases the odds of trying other drugs such as cannabis, cocaine and prescription drugs ${ }^{(34)}$.

Although cocaine showed no influence on the presence of mental distress among the women in this study, its use, even in small doses, acts on the loss of the vesicular monoamine transporter 2 (VMAT2) protein. VMAT2 is responsible for the transport of monoamines and thus causes damage to the dopaminergic system which can result in mood disorders ${ }^{(35)}$.

A systematic review investigating the frequency of psychoactive substance use disorders in China and India found that among women, anxiety disorders, major depressive disorder and dysthymia were the most commonly associated with psychoactive substance use $\mathrm{e}^{(36)}$.

There has been an increase in the presence of women in the context of alcohol and other drugs, however, the social stigma related to this consumption seems to make it difficult for them to seek health services to overcome this harmful habit. Most of the women in this study reported seeking service merely on a routine basis.

This reality should be viewed with concern by health professionals, because although women are those who seek health care the most, there is a fragility of policies that prevent the tracking of alcohol, other drugs and mental distress.

In this sense, one must understand this problem beyond the biomedical dimensions. A broader view of the health/disease process that addresses the specificities of women as a social subject is essential. Therefore, women should be seen not only with the uniqueness of their disorders but with the plurality of their daily reality, developing actions that involve their professional, family and affective life.

\section{Study limitations}

The cross-sectional design makes it impossible to define a causal relationship, since exposure and outcome were measured simultaneously. Nevertheless, the found associations cannot be considered causal due to the possibility of reverse causality.

\section{Contributions to nursing, health or public policy}

Indicators point out that women's alcohol and other drug use has specific characteristics and implications and therefore needs particular interventions. This conception is not always recognized by the policy management and services that make up the healthcare network for these clients.

Given this outcome, recommendations for management and nursing care include the implementation of tools for tracking 
alcohol, other drug use, and mental distress in the routine of primary care nursing consultations. These problems are commonly encountered in this device, and the absence of measuring instruments to help conduct qualified listening potentiate the difficulties in identifying psychoactive substance use and mental distress. In this sense, the formation of human resources inserted in the various care devices that make up the health care network based on permanent education strategies is fundamental.

\section{CONCLUSION}

The study shows that alcohol consumption is associated with mental distress in the researched group. Women with zone IV alcohol consumption (possible addiction) are more likely to have mental distress. The correlation test reinforced this outcome by demonstrating that the more intense alcohol consumption the higher the level of mental distress.

Tobacco, tranquilizers, and cannabis use is also associated with mental distress. Tobacco use increases by 3.5 times the odds for distress, tranquilizers by 2.6 times and cannabis by 4.5 times. Comparison of SRQ-20 score means confirms these findings, since the use of these substances makes the mean of this score predictive of mental distress.

\section{FUNDING}

This research was funded by the Brazilian National Council for Scientific and Technological Development (CNPq - Conselho Nacional de Desenvolvimento Científico e Tecnológico) (Process 443107/2014-9).

\section{REFERENCES}

1. Cruz VD, Oliveira MM, Pinho LB, Coimbra VCC, Kantorski LP, Oliveira JF. Sociodemographic conditions and patterns of crack use among women. Texto Contexto Enferm. 2014;23(4):1068-76. doi: 10.1590/0104-07072014000580013

2. Ramakrishnan S, Kinatingal PJ, Chakkalakkudy G, Kuttichira P, Antony JT, Beevi S. Alcohol consumption in a woman in rural setting of Kerala. Kerala J Psychiatr [Internet]. 2017 [cited 2018 Jan 10];30(1):1-3. Available from: http://kjponline.com/index.php/kjp/article/view/111/pdf

3. Coutinho LMS, Matijasevich A, Scazufca M, Menezes PR. Prevalência de transtornos mentais comuns e contexto social: análise multinível do São Paulo Ageing \& Health Study (SPAH). Cad Saúde Pública. 2014;30(9):1875-83. doi: 10.1590/0102-311X00175313

4. Skapinakis P, Bellos S, Koupidis S, Grammatikopoulos I, Theodorakis PN, Mavreas V. Prevalence and sociodemographic associations of common mental disorders in a nationally representative sample of the general population of Greece. BMC Psychiatry. 2013;13:163. doi: $10.1186 / 1471-244 X-13-163$

5. Lucchese R, Sousa K, Bonfin SP, Vera I, Santana FR. Prevalence of common mental disorders in primary health care. Acta Paul Enferm. 2014;27(3):200-7. doi: 10.1590/1982-0194201400035

6. Instituto Brasileiro de Geografia e Estatística (IBGE). Censo Demográfico 2010 [Internet]. Rio de Janeiro: IBGE; 2015 [cited 2015 Aug 05 ]. Available from: https://censo2010.ibge.gov.br/

7. Laranjeira R, organizador. II Levantamento Nacional de Álcool e Drogas (LENAD) [Internet]. São Paulo: Instituto Nacional de Políticas Públicas do Álcool e Outras Drogas (INPAD); 2012 [cited 2014 Aug 25]. Available from: https://inpad.org.br/wp-content/uploads/2014/03/ Lenad-II-Relat\%C3\%B3rio.pdf

8. Lima CT, Freire AC, Silva AP, Teixeira RM, Farrell M, Prince M. Concurrent and construct validity of the AUDIT in an urban Brazilian sample. Alcohol Alcohol. 2005;40(6):584-9. doi: 10.1093/alcalc/agh202

9. Smart RG, Arif A, Hughes PH, Medina ME, Navaratnam V, Varma VK, et al. Drug use among non-student youth. WHO Offset Publ [Internet]. 1981 [cited 2015 Mar 22];60(1):1-58. Available from: https://apps.who.int/iris/handle/10665/39190

10. Mari JJ. Psychiatric morbidity in three primary medical care clinics in the city of São Paulo: issues on the mental health of the urban poor. Soc Psychiatry. 1987;22(3):129-38. doi: 10.1007/BF00583847

11. Santos NS, Souza EFM, Aquino AP, Santos JN, Bissaco DM, Suano ER, et al. A orientação de enfermagem em gestantes que fazem uso do álcool e tabaco. Rev Recien. 2014;4(10):5-11. doi: 10.24276/rrecien2358-3088.2014.4.10.5-11

12. Borges TL, Hegadoren KM, Miasso Al. Transtornos mentais comuns e uso de psicofármacos em mulheres atendidas em unidades básicas de saúde em um centro urbano brasileiro. Rev Panam Salud Publica [Internet]. 2015 [cited 2017 Jun 06];38(3):195-201. Available from: https:// scielosp.org/pdf/rpsp/2015.v38n3/195-201/pt

13. Arruda RL, Teles ED, Machado NS, Oliveira FJF, Fontoura IG, Ferreira AGN, Machado NS. Prevenção do câncer de mama em mulheres atendidas em Unidade Básica de Saúde. Rev Rene [Internet]. 2015 [cited 2017 Jun 06];16(2):143-9. Available from: http://periodicos.ufc.br/ rene/article/view/2692

14. World Health Organization (WHO). Relatório mundial sobre violência e saúde [Internet]. Genebra: WHO; 2016 [cited 2017 Jan 08 ]. Available from: https://www.opas.org.br/wp-content/uploads/2015/09/relatorio-mundial-violencia-saude.pdf

15. Laranjeira R, Mitsuhiro SS. Addiction research centres and the nurturing of creativity. National institute on alcohol and drugs policies, Brazil. Addiction. 2011;107(4):727-32. doi: 10.1111/j.1360-0443.2011.03380.x

16. Hoggatt KJ, Jamison AL, Lehavot K, Cucciare MA, Timko C, Simpson T. Alcohol and drug misuse, abuse, and dependence in women veterans. Epidemiol Rev. 2015;37:23-37. doi: 10.1093/epirev/mxu010 
17. Laranjeira R, (Org). I Levantamento Nacional de Álcool e Drogas (LENAD). São Paulo: Instituto Nacional de Políticas Públicas do Álcool e Outras Drogas (INPAD); 2006.

18. Lombardi EMS, Prado GF, Santos UP, Fernandes FLA. Women and smoking: risks, impacts, and challenges. J Bras Pneumol. 2011;37(1):118-28. doi: 10.1590/S1806-37132011000100017

19. United Nations (UN). United Nations Office on Drugs and Crime (UNODC). World Drug Report [Internet]. Geneva: UNODC; 2016 [cited 2016 Dec 20]. Available from: https://www.unodc.org/wdr2016/

20. Priester MA, Browne T, lachini A, Clone SMSW, DeHart D, Seay KD. Treatment access barriers and disparities among individuals with cooccurring mental health and substance use disorders: an integrative literature review. J Subst Abuse Treat. 2016;61:47-59. doi: 10.1016/j. jsat.2015.09.006

21. Wiemann I, Munhoz TN. Prevalência de transtornos mentais comuns e fatores associados nos usuários do centro de referência de assistência social de São Lourenço do Sul, RS. Ensaios Ciênc Biol Agrar Saúde. 2015;19(2):89-94. doi: 10.17921/1415-6938.2015v19n2p\%25p

22. Malhotra S, Shah R. Women and mental health in India: an overview. Indian J Psychiatry. 2015;57(2):S205-S211. doi: 10.4103/0019-5545.161479

23. Fonseca MLG, Guimarães MBL, Vasconcelos EM. Sofrimento difuso e transtornos mentais comuns: uma revisão bibliográfica. Rev APS [Internet]. 2008 [cited 2017 Jan 13];11(3):285-94. Available from: https://periodicos.uff.br/index.php/aps/article/view/14269

24. Esper LH, Corradi-Webster CM, Carvalho AMP, Furtado EF. Women in outpatient treatment for alcohol abuse: sociodemographic and clinical characteristics. Rev Gaúcha Enferm. 2013;34(2):93-101. doi: 10.1590/S1983-14472013000200012

25. Pereira RC, Sougey EB, Lima MDC. Dependência de álcool e depressão: diálogo com as pesquisas e rastreio dessa relação. Rev Bras Ciênc Saúde. 2014;18(1):214-24.

26. Kuria MW, Ndetei DM, Obot IS, Khasakhala LI, Bagaka BM, Mbugua MN, et al. The association between alcohol dependence and depression before and after treatment for alcohol dependence. ISRN Psychiatry. 2012;2012:482802. doi: 10.5402/2012/482802

27. Boden JM, Fergusson DM. Alcohol and depression. Addiction. 2011;106(5):906-14. doi: 10.1111/j.1360-0443.2010.03351.x

28. Pawlina MMC, Rondina RC, Espinosa MM, Botelho C. Depression, anxiety, stress, and motivation over the course of smoking cessation treatment. J Bras Pneumol. 2015;41(5):433-9. doi: 10.1111/j.1360-0443.2010.03351.x

29. Farmer RF, Kosty DB, Seeley JR, Duncan SC, Lynskey MT, Rohde P, et al. Natural course of cannabis use disorders. Psychol Med. 2015;45(1):6372. doi: 10.1017/S003329171400107X

30. Sartor CE, Agrawal A, Lynskey MT, Duncan AE, Grant JD, Nelson EC, et al. Cannabis or alcohol first? differences by ethnicity and in risk for rapid progression to cannabis-related problems in women. Psychol Med. 2013 Apr;43(4):813-23. doi: 10.1017/\$0033291712001493

31. Nebhinani N, Sarkar S, Gupta S, Mattoo SK, Basu D. Demographic and clinical profile of substance abusing women seeking treatment at a de-addiction center in north India. Ind Psychiatry J. 2013;22(1):12-6. doi: 10.4103/0972-6748.123587

32. Smith SM, Goldstein RB, Grant BF. The association between post-traumatic stress disorder and lifetime DSM-5 psychiatric disorders among veterans: data from the National Epidemiologic Survey on Alcohol and Related Conditions-III (NESARC-III). J Psychiatr Res. 2016;82:16-22. doi: 10.1016/j.jpsychires.2016.06.022

33. Eaton NR, Rodriguez-Seijas C, Krueger RF, Campbell WK, Grant BF, Hasin DS. Narcissistic Personality Disorder and the Structure of Common Mental Disorders. J Pers Disord. 2017;31(4):449-61.doi: 10.1521/pedi_2016_30_260

34. Castaldelli-Maia JM, Nicastri S, Oliveira LG, Andrade AG, Martins SS. The role of first use of inhalants within sequencing pattern of first use of drugs among Brazilian university students. Exp Clin Psychopharmacol. 2014;22(6):530-40. doi: 10.1037/a0037794

35. Little KY, Krolewski DM, Zhang L, Cassin BJ. Loss of Striatal Vesicular Monoamine Transporter Protein (VMAT2) in Human Cocaine Users. Am J Psychiatry. 2003;160(1):47-55. DOI: 10.1176/appi.ajp.160.1.47

36. Baxter A, Charlson FJ, Cheng HG, Shidhaye R, Ferrari AJ, Whiteford HA. Prevalence of mental, neurological, and substance use disorders in China and India: a systematic analysis. Lancet Psychiatry. 2016;3(9):832-41. doi: 10.1016/S2215-0366(16)30139-0 